Vol. 7 No. 2 Juli 2018

E-ISSN : 2502-3101 P-ISSN : 2302-528x

http://ojs.unud.ac.id/index.php/jmhu

\title{
Urgensi Pembentukan Peradilan Khusus Pemilu dalam rangka Mewujudkan Integritas Pemilu
}

\author{
Iwan Rois', Ratna Herawati ${ }^{2}$ \\ 1Program Studi Magister Ilmu Hukum Universitas Diponegoro, E-mail: iwan_rois@gmail.com \\ 2Program Studi Magister Ilmu Hukum Universitas Diponegoro, E-mail: $\underline{\text { ratna_h27@yahoo.com }}$
}

\begin{tabular}{l}
\hline Info Artikel \\
\hline Masuk: 3 Juli 2018 \\
Diterima: 18 Juli 2018 \\
Terbit: 31 Juli 2018 \\
Keywords: \\
Law enforcement; Election- \\
specific judiciary; General \\
Election \\
\\
\\
Kata kunci: \\
Penegakan hukum; Peradilan \\
khusus pemilu; Pemilihan \\
Umum \\
Corresponding Author: \\
Iwan Rois, E-mail: \\
iwan_rois@gmail.com \\
DOI: \\
10.24843/JMHU.2018.v07.i02 \\
p10
\end{tabular}

\begin{abstract}
This study aims to analyze the need to establish a special election court which has the authority to solve various election law cases in order to realize elections with integrity; and analyzing the formulation of election special justice in order to realize the integrity of the election. The research method used is the method of normative legal research and the implementation of this research collects data from various sources in order to get an answer to the issues that have been formulated. The results of the study show that the purpose of the need for the formation of special judicial elections; First, to meet the growing demands of increasingly complex justice in society and more election law enforcement so as to realize the integrity of the elections; Second, to handle the election law cases quickly and simply so as to obey the integrity of the election. Formulation; First, the election special justice to be able to work quickly and simply in handling election law cases, domiciled at the central and provincial level, then entering the District Court or the High Court; Secondly, the Guidelines for the election special judicial law shall be based on Supreme Court Regulation Number 4 Year 2017 on Procedures for the Settlement of Administrative Offenses of the General Elections in the Supreme Court.
\end{abstract}

Abstrak

Penelitian ini bertujuan untuk menganalisis perlunya membentuk peradilan khusus pemilu yang mempunyai kewenangan menyelesaikan berbagai perkara hukum pemilu agar terwujud pemilu yang berintegritas; dan menganalisis formulasi pembentukan peradilan khusus pemilu dalam rangka mewujudkan integritas pemilu. Metode penelitian yang digunakan ialah metode penelitian hukum normatif dan pelaksanaan dari penelitian ini mengumpulkan bahan hukum dari berbagai sumber guna mendapatkan suatu jawaban atas pokokpokok permasalahan yang telah dirumuskan. Hasil penelitian menunjukkan bahwa tujuan perlunya pembentukan peradilan khusus pemilu; Pertama, Untuk memenuhi tuntutan perkembangan akan keadilan yang semakin kompleks dalam masyarakat dan lebih penegakan hukum pemilu sehingga mewujudkan integritas pemilu; Kedua, Untuk menangani perkara hukum pemilu dengan cepat dan sederhana sehingga mewujudkan integritas pemilu. Formulasi; Pertama, Peradilan khusus pemilu agar bisa bekerja cepat dan sederhana dalam menangani perkara hukum pemilu, berkedudukan di tingkat pusat dan provinsi, selanjutnya masuk pada Pengadilan Negeri atau Pengadilan Tinggi; Kedua, Pedoman beracara pada peradilan khusus pemilu 
berdasarkan pada Peraturan Mahkamah Agung Nomor 4 Tahun 2017 tentang Tata Cara Penyelesaian Pelanggaran Administratif Pemilihan Umum Di Mahkamah Agung.

\section{Pendahuluan}

Pancasila sebagai falsafah negara Indonesia sebagaimana tercantum dalam pembukaan Undang-Undang Dasar Negara Republik Indonesia 1945 (yang selanjutnya disebut dengan UUD NRI Tahun 1945). Pada alenia keempat pembukaan UUD NRI Tahun 1945 ditegaskan secara tekstual "Maka disusunlah kemerdekaan kebangsaan Indonesia itu dalam suatu UUD NRI Tahun 1945, yang terbentuk dalam suatu susunan Negara Republik Indonesia yang berkedaulatan rakyat yang berdasarkan Kepada Ke Tuhanan." Mengacu ketentuan sebagaimana pada pembukaan UUD NRI Tahun 1945, diatas mengisyaratkan bahwa dalam setiap penyelenggaraan pemerintahan harus berdasarkan UUD NRI Tahun 1945 sebagai hukum tertinggi, sekaligus memberikan kekuasaan tertinggi pada rakyat.

Pembukaan UUD NRI Tahun 1945, pada alenia keempat sebagaimana diatas selanjutnya diejawantahkan pada ketentuan Pasal 1 ayat (3) UUD NRI Tahun 1945, menyebutkan bahwa "Negara Indonesia adalah negara hukum." Berdasarkan pada pembukaan UUD NRI Tahun 1945 diatas bahwa Indonesia sebagai negara berdasarkan atas hukum, maka dalam setiap penyelenggaraan negara harus berdasarkan undang-undang atau peraturan yang berlaku yang telah di tetapkan oleh eksekutif dan legislatif sebagai wakil rakyat. Begitu juga dalam pemilihan pemimpin untuk mengisi organ negara yang dilaksanakan melalui pemilihan umum (yang selanjutnya disebut dengan pemilu).

Pemilihan Umum merupakan proses politik dalam kehidupan ketatanegaraan sebagai sarana menunjuk pembentukan lembaga-lembaga perwakilan yang mengemban amanat rakyat. Menurut Sri Soemantri sebagaimana dikutip dalam buku Sodikin menyebutkan bahwa pemilu yang dilaksanakan harus merupakan pemilihan umum yang bebas, sebagai syarat mutlak bagi berlakunya demokrasi, dan dapat dihubungkan dengan kenyataan di mana nilai suatu pemerintahan untuk sebagian besar bergantung kepada orang-orang yang duduk di dalamnya. ${ }^{1}$ Sebagaimana dikutip dari studi yang dilakukan oleh Mujiatum yaitu pemilu bertujuan untuk memilih wakil rakyat yang akan menjalankan fungsi pengawasan, menyalurkan aspirasi politik membuat undang-undang sebagai landasan semua pihak, merumuskan anggaran pendapatan dan belanja untuk membiayai fungsi-fungsi tersebut. ${ }^{2} \mathrm{Hal}$ tersebut merupakan suatu bentuk partisipasi politik dari rakyat untuk menentukan pemerintahan yang sesuai dengan keinginan hati nurani mereka, dimana mereka mendukung atau menerima program-program pemerintah yang didukung mereka.

Pemilu dalam proses penyelenggaraannya bukan berarti tidak akan timbul permasalahan, penyelenggaraan pemilu yang diselenggarakan selalu terjadi permasalahan yang akan muncul dari awal penyelenggaraan hingga akhir penyelenggaraan. Misalnya pelanggaran administrasi, pelanggaran pidana dan perselisihan perolehan suara hasil pemilu (yang selanjutnya disebut

\footnotetext{
1 Sodikin. (2014). Hukum Pemilu; Pemilu Sebagai Praktek Ketatanegaraan. Gramata Publishing. Bekasi. h. 3.

2 Mujiatun, M. (2017). Permasalahan Hukum Terhadap Pelanggaran Pemilu. Jurnal An-Nur. 1(01). h. 61
} 
perkara pemilu). Sebagaimana dalam Pasal 460 ayat (1), 473 ayat (1), 476 ayat (2) UndangUndang Nomor 7 Tahun 2017 Tentang Pemilihan Umum. Sebagai berikut:

Sebagaimana pada ketentuan Pasal 460 ayat (1) mengatur bahwa "Pelanggaran administrasi pemilu meliputi pelanggaran terhadap tata cara, prosedur, atau mekanisme yang berkaitan dengan administrasi pelaksanaan pemilu dalam setiap tahapan penyelenggaraan pemilu." Selanjutnya pada ketentuan Pasal 473 ayat (1) menyebutkan bahwa "Perselisihan hasil pemilu meliputi perselisihan antara KPU dan peserta pemilu mengenai perolehan suara hasil pemilu secara nasional." Pasal 476 ayat (2) menyebutkan bahwa "Perbuatan atau tindakan yang diduga merupakan tindakan pidana pemilu dinyatakan oleh Bawaslu."

Putusan MK No 97/PUU-XI/2013 pengujian Undang-Undang Nomor 12 tahun 2008 tentang perubahan kedua atas Undang-Undang Nomor 32 tahun 2004 tentang Pemerintahan Daerah dan Undang-Undang Nomor 48 tahun 2009 tentang Kekuasaan Kehakiman terhadap UUD NRI Tahun 1945. Putusan Mahkamah Konstitusi menyebutkan "Berdasarkan amanat Konstitusi pada BAB VIIB tentang Pemilihan Umum, Pasal 22E ayat (2) UUD NRI Tahun 1945 dikatakan bahwa Pemilihan umum diselenggarakan untuk memilih anggota Dewan Perwakilan Rakyat, Dewan Perwakilan Daerah, Presiden dan Wakil Presiden dan Dewan Perwakilan Rakyat Daerah. Dalam hal ini penyelenggaraan pemilu yang diatur dalam konstitusi tidak menyebutkan untuk memilih kepala daerah. sementara tentang pemilihan kepala daerah dalam UUD NRI Tahun 1945, ditulis pada BAB yang berbeda, yaitu BAB IV tentang Pemerintahan Daerah, pada Pasal 18 ayat (4) yang berbunyi “Gubernur dan Walikota masing-masing sebagai kepala pemerintah provinsi, kabupaten dan kota dipilih secara demokratis. Artinya konstitusi sendiri tidak memasukkan pemilihan kepala daerah ke dalam bab yang mengatur tentang pemilu. dapat dikatakan pemilihan kepala daerah tidak tergolong dalam rezim pemilu. Itu sebabnya dalam Pasal 22E ayat (2) UUD NRI Tahun 1945 tidak memasukkan frase kepala daerah dalam BAB pemilihan umum.

Sebagaimana pada uraian diatas bahwa pilkada bukan rezim pemilu dipertegas dengan lahirnya Undang-Undang Nomor 7 tahun 2017 tentang Pemilihan Umum, yang tidak menyebutkan pemilu untuk memilih kepala daerah. Hal tersebut sebagaimana pada ketentuan Pasal 1 angka 1 mengatur bahwa: Pemilihan umum yang dilaksanakan secara langsung, umum, bebas, rahasia, jujur, dan adil dalam Negara kesatuan Republik Indonesia berdasarkan Pancasila dan UUD NRI Tahun 1945, merupakan sarana kedaulatan rakyat untuk memilih anggota DPR, anggota DPD, Presiden dan Wakil Presiden, dan DPRD. Sedangkan dalam Undang-Undang Nomor 8 tahun 2015 tentang Penetapan Peraturan Pemerintah Pengganti Undang-Undang Nomor 1 tahun 2014 tentang Pemilihan Gubernur, Bupati, Dan Walikota Menjadi Undang-Undang, pada Pasal 1 mengatur bahwa:

"Pemilihan Gubernur dan Wakil Gubernur, Bupati dan Wakil Bupati, serta Walikota dan Wakil Walikota yang selanjutnya disebut Pemilihan adalah pelaksanaan kedaulatan rakyat di wilayah provinsi dan kabupaten/kota untuk memilih Gubernur dan Wakil Gubernur, Bupati dan Wakil Bupati, Walikota dan Wakil Walikota secara langsung dan demokratis."

Sebagaimana ketentuan Pasal di atas tidak menyebutkan untuk memilih anggota Dewan Perwakilan Rakyat, anggota Dewan Perwakilan Daerah, Presiden dan Wakil Presiden, dan untuk memilih Dewan Perwakilan Rakyat Daerah. Sementara itu dari berbagai pemberitaan media massa juga dapat diketahui oleh publik bahwa dalam penyelenggaraan pemilu yang lalu sering terjadi berbagai pelanggaran dalam proses pelaksanaan Pemilu Legislatif, seperti 
kekacauan mengenai Daftar Pemilih Tetap (DPT), banyaknya warga negara yang kehilangan hak pilihnya, money politic, tertukarnya surat suara, masalah logistik Pemilu, dan sebagainya. ${ }^{3}$ Laporan pelanggaran dugaan money politic yang terjadi selama tahapan masa tenang, tahapan pemungutan hingga penghitungan suara ditangani oleh panitia pengawas. ${ }^{4}$ Kasus money politics tidak hanya terjadi pada Pelaksanaan Pemilu namun juga pada Pemilukada. Money Politic dalam pelaksanaan pemilukada bahkan dilakukan secara sistematik, terstruktur dan massif. ${ }^{5}$ Pemilu serentak sesungguhnya dimaksudkan sebagai upaya meminimalisasi praktikpraktik buruk demokrasi langsung yang transaksional serta koruptif. ${ }^{6}$ Berkaitan dengan Pemilu serentak, terlihat ada beberapa keuntungannya seperti bertujuan menciptakan hasil pemilu yang kongruen; mendorong terciptanya koalisi berbasis kebijakan; mendorong kualitas Parpol yang lebih demokratis; potensial meminimalkan konflik antar partai atau pendukung partai. ${ }^{7}$ Namun demikian, konflik maupun pelanggaran tidak selalu dapat dihindarkan baik dalam pelaksanaan pemilukada yang dilakukan secara serentak maupun pelaksanaan Pemilu.

Sehubungan dengan berbagai pelanggaran yang terjadi maka bagaimana mekanisme dan prosedur hukum dalam menyelesaikan berbagai masalah tersebut yang telah mengganggu penyelenggaraan negara. Selain itu perlukah membentuk sebuah peradilan khusus pemilu yang mempunyai wewenang untuk menyelesaikan berbagai perkara hukum pemilu tersebut agar terwujud pemilu yang berintegritas. Sebagaimana uraian yang telah disampaikan diatas dengan adanya berbagai bentuk perkara hukum pemilu yang kerap terjadi dalam penyelenggaraan pemilu, maka rumusan masalah yang dikaji dalam penelitian ini sebagai berikut: Pertama, mengapa diperlukan pembentukan peradilan khusus pemilu? Kedua, Bagaimana formulasi pembentukan peradilan khusus pemilu dalam rangka mewujudkan integritas pemilu?

Berdasarkan permasalahan tersebut di atas, maka tujuan kajian ini adalah untuk menganalisis perlunya membentuk peradilan khusus pemilu yang mempunyai wewenang untuk menyelesaikan berbagai perkara hukum agar terwujud pemilu yang berintegritas, serta bertujuan untuk menganalisis formulasi pembentukan peradilan khusus pemilu dalam rangka mewujudkan integritas pemilu.

\section{Metode Penelitian}

Sebagaimana dinyatakan Abdulkadir Muhamad, 8 bahwa penelitian hukum normatif adalah penelitian hukum yang mengkaji hukum tertulis dari berbagai aspek yaitu aspek teori, sejarah,

${ }^{3}$ Fadjar, A. M. (2013). Pemilu Perselisihan Hasil Pemilu dan Demokrasi (Membangun Pemilu Legislatif, Presiden, dan Kepala Daerah \& Penyelesaian Perselisihaan Hasil Pemilu Secara Demokratis). Setara Presss. Malang. h. 23-24

${ }^{4}$ Makhsid, W. (2015). Upaya Panitia Pengawas Pemilu Kabupaten Banyumas Dalam Pencegahan Tindak Pidana Money Politic Pada Pemilihan Umum Legislatif Tahun 2014. Jurnal Idea Hukum. 1(2). h. 174

5 Saraswati, R. (2014). Reorientasi Hukum Pemilukada yang Mensejahterakan Rakyatnya. Jurnal Dinamika Hukum. 14(2). h. 361

${ }^{6}$ Arrsa, R. C. (2014). Pemilu Serentak dan Masa Depan Konsolidasi Demokrasi. Jurnal Konstitusi. 11(3). h. 535-536

7 Prasetyoningsih, N. (2014). Dampak Pemilihan Umum Serentak Bagi Pembangunan Demokrasi Indonesia. Jurnal Media Hukum. 21(2). h.261

${ }^{8}$ Muhamad, A. (2004).Hukum dan Penelitian Hukum. Citra Aditya Bakti. Bandung. h. 101-102 
filosofi, perbandingan, struktur dan komposisi, lingkup dan materi, konsistensi, penjelasan umum dan Pasal demi Pasal, formalitas dan mengikatnya suatu undang-undang serta bahasa hukum yang digunakan. Penelitian hukum yang dilakukan dengan cara meneliti bahan pustaka atau data sekunder, dapat dinamakan penelitian hukum normatif atau penelitian hukum kepustakaan. ${ }^{9}$ Sehubungan dengan hal tersebut, maka penelitian ini menggunakan metode penelitian hukum normatif dan dengan pendekatan perundang-undangan serta putusan Mahkamah Konstitusi.

\section{Hasil dan Pembahasan}

\subsection{Putusan Mahkamah Konstitusi Nomor 97/PUU-XI/2013}

Putusan MK No 97/PUU-XI/2013 pengujian Undang-Undang Nomor 12 tahun 2008 tentang perubahan kedua atas Undang-Undang Nomor 32 tahun 2004 tentang Pemerintahan Daerah dan Undang-Undang Nomor 48 tahun 2009 tentang Kekuasaan Kehakiman terhadap UUD NRI Tahun 1945. Putusan Mahkamah Konstitusi menyebutkan "Berdasarkan amanat Konstitusi pada BAB VIIB tentang Pemilihan Umum, Pasal 22E ayat (2) UUD NRI Tahun 1945 dikatakan bahwa Pemilihan umum diselenggarakan untuk memilih anggota Dewan Perwakilan Rakyat, Dewan Perwakilan Daerah, Presiden dan Wakil Presiden dan Dewan Perwakilan Rakyat Daerah. Dalam hal ini penyelenggaraan pemilu yang diatur dalam konstitusi tidak menyebutkan untuk memilih kepala daerah. sementara tentang pemilihan kepala daerah dalam UUD NRI Tahun 1945, ditulis pada BAB yang berbeda, yaitu BAB IV tentang Pemerintahan Daerah, pada Pasal 18 ayat (4) yang berbunyi “Gubernur dan Walikota masing-masing sebagai kepala pemerintah provinsi, kabupaten dan kota dipilih secara demokratis. Artinya konstitusi sendiri tidak memasukkan pemilihan kepala daerah ke dalam bab yang mengatur tentang pemilu, dapat dikatakan pemilihan kepala daerah tidak tergolong dalam rezim pemilu. Itu sebabnya dalam Pasal 22E ayat (2) UUD NRI Tahun 1945 tidak memasukkan frase kepala daerah dalam $B A B$ pemilihan umum.

Sebagaimana pada uraian diatas bahwa pilkada bukan rezim pemilu dipertegas dengan lahirnya Undang-Undang Nomor 7 tahun 2017 tentang Pemilihan Umum, yang tidak menyebutkan pemilu untuk memilih kepala daerah. Hal tersebut sebagaimana Pada ketentuan Pasal 1 angka 1 mengatur bahwa:

"Pemilihan Umum yang selanjutnya disebut Pemilu adalah sarana kedaulatan rakyat untuk memilih anggota Dewan Perwakilan Rakyat, anggota Dewan Perwakilan Daerah, Presiden dan wakil Presiden, dan untuk memilih Dewan Perwakilan Rakyat Daerah, yang dilaksanakan secara langsung umum, bebas, rahasia, jujur, dan adil dalam Negara Kesatuan Republik Indonesia berdasarkan Pancasila dan UndangUndang dasar Negara Republik Indonesia Tahun 1945."

Sedangkan dalam Undang-Undang Nomor 8 tahun 2015 tentang Penetapan Peraturan Pemerintah Pengganti Undang-Undang Nomor 1 tahun 2014 tentang Pemilihan Gubernur, Bupati, Dan Walikota Menjadi Undang-Undang, pada Pasal 1 ayat angka 1 menyebutkan bahwa:

"Pemilihan Gubernur dan Wakil Gubernur, Bupati dan Wakil Bupati, serta Walikota dan Wakil Walikota yang selanjutnya disebut Pemilihan adalah pelaksanaan kedaulatan rakyat di wilayah provinsi dan kabupaten/kota untuk memilih Gubernur dan Wakil Gubernur, Bupati dan Wakil Bupati, Walikota dan Wakil Walikota secara langsung dan demokratis."

${ }^{9}$ Ibid. h. 13-14 
Sebagaimana ketentuan Pasal diatas tidak menyebutkan untuk memilih anggota Dewan Perwakilan Rakyat, anggota Dewan Perwakilan Daerah, Presiden dan Wakil Presiden, dan untuk memilih Dewan Perwakilan Rakyat Daerah.

\subsection{Gagasan Pembentukan Peradilan Khusus Pemilu}

Undang-Undang Nomor 48 tahun 2009 tentang Kekuasaan Kehakiman, mengatur tentang pembentukan pengadilan khusus yang kewenangannya untuk memeriksa, mengadili dan memutus perkara tertentu. Hal tersebut diatur dalam ketentuan Pasal 1 angka 8 yang menyebutkan bahwa:

"Pengadilan Khusus adalah pengadilan yang mempunyai kewenangan untuk memeriksa, mengadili dan memutus perkara tertentu yang hanya dapat dibentuk dalam salah satu lingkungan badan peradilan yang berada di bawah Mahkamah Agung yang diatur dalam undang-undang."

Pengadilan khusus yang pernah ada dasar pengkhususannya dapat dibagi dua, yaitu: pengadilan yang kekhususannya karena hukum materiil yang menjadi ruang lingkupnya, dan pengadilan yang kekhususannya karena subjek yang terlibat. Pengadilan khusus yang termasuk dalam kategori pertama yaitu pengadilan ekonomi, pengadilan niaga, pengadilan HAM, pengadilan pajak dan pengadilan perikanan. Pada pengadilan tersebut kompetensi absolutnya berkaitan dengan objek hukum, maksudnya setiap perkara yang termasuk dalam objek hukum tertentu menjadi wewenang pengadilan ini. Pada pengadilan ekonomi setiap perkara tindak pidana ekonomi menjadi wewenang pengadilan ekonomi, pada pengadilan niaga setiap perkara kepailitan, penundaan kewajiban pembayaran utang dan HAKI merupakan wilayah pengadilan niaga. Pada pengadilan pajak, sengketa pajak yang menjadi ruang lingkupnya. Pada pengadilan HAM memeriksa pelanggaran HAM berat, Pengadilan PHI memeriksa perselisihan hubungan industrial, dan pada pengadilan perikanan yaitu tindak pidana perikanan yang diatur dalam undang-undang perikanan. Kategori yang menjadi dasar kekhususan adalah subjek yang terlibat. Pada pengadilan anak, subjek yang menjadi sumber kekhususan adalah tersangka/terdakwa, dalam hal ini anak yang berusia antara 8 - 18 tahun. ${ }^{10}$

Sehubungan dengan ketentuan diatas dalam Undang-Undang Nomor 7 Tahun 2017 tentang Pemilihan Umum, mengatur tentang pelanggaran administrasi dan tindak pidana pemilu. Hal tersebut sebagaimana terdapat pada ketentuan Pasal 460 ayat (1) dan (2), dan Pasal 476 ayat (2), sebagai berikut:

Pasal 460 ayat (1) Menyebutkan bahwa "Pelanggaran administrasi pemilu meliputi pelanggaran terhadap tata cara, prosedur, atau mekanisme yang berkaitan dengan administrasi pelaksanaan pemilu dalam setiap tahapan penyelenggaraan pemilu." ayat (2) menyebutkan bahwa "Pelanggaran administratif sebagaimana dimaksud pada ayat (1) tidak termasuk tindak pidana pemilu dan pelanggaran kode etik."Pasal 476 ayat (2) Menyebutkan "Perbuatan atau tindakan yang diduga merupakan tindakan pedana pemilu dinyatakan oleh bawaslu."

Undang-Undang Nomor 42 tahun 2008 tentang Pemilihan Presiden dan Wakil Presiden, mengatur pelanggaran administrasi pada ketentuan Pasal 192, dan pelanggaran pidana pemilu diatur dalam Pasal 195, yang menyebutkan sebagai berikut:

${ }^{10 h t t p s: / / t i a r r a m o n . w o r d p r e s s . c o m / 2010 / 07 / 14 / p e n g a d i l a n-p e n g a d i l a n-k h u s u s-d i-i n d o n e s i a / . ~}$

(Diakses 3 Mei 2018) 
Pasal 192 menyebutkan bahwa "Pelanggaran administrasi pemilu Presiden dan Wakil Presiden diselesaikan oleh KPU, KPU provinsi, dan KPU kabupaten/kota berdasarkan laporan dari Bawaslu, Panwaslu Provinsi, dan Panwaslu kabupaten/kota sesuai dengan tingkatannya."Pasal 195 menyebutkan bahwa "Pelanggaran pidana pemilu Presiden dan Wakil Presiden adalah pelanggaran terhadap ketentuan pidana pemilu Presiden dan Wakil Presiden yang diatur dalam Undang-Undang ini yang penyelesaiannya dilaksanakan melalui pengadilan dalam lingkungan peradilan umum."

Undang-Undang Nomor 8 Tahun 2012 Tentang Pemilihan Umum Anggota Dewan Perwakilan Rakyat, Dewan Perwakilan Daerah dan Dewan Perwakilan Rakyat Daerah. mengatur tentang pelanggaran pemilu pada ketentuan Pasal 253 dan pidana pemilu diatur pada ketentuan Pasal 260, sebagai berikut:

Pasal 253 menyebutkan bahwa "Pelanggaran administrasi pemilu adalah pelanggaran yang meliputi tata cara, prosedur, dan mekanisme yang berkaitan dengan administrasi pelaksanaan pemilu dalam setiap tahapan penyelenggaraan pemilu di luar tindak pidana pemilu dan pelanggaran kode etik penyelenggara pemilu." Pasal 260 menyebutkan bahwa "Tindak pidana pemilu adalah tindak pidana pelanggaran dan/atau kejahatan terhadap ketentuan tindak pidana pemilu sebagaimana diatur dalam Undang-Undang ini."

Sebagaimana dari uraian diatas maka pengkhususan dalam perkara hukum pemilu pada pemilu DPR, DPD, Presiden dan Wakil Presiden, dan DPRD, dilihat dari hukum meteriilnya yang menjadi ruang lingkupnya meliputi tata cara, prosedur, dan mekanisme yang berkaitan dengan pelaksanaan pemilu dalam setiap penyelenggaraan pemilu, dan tindak pidana pelanggaran dan/atau kejahatan terhadap ketentuan tindak pidana pemilu. Mengacu hal tersebut maka diperlukan peradilan khusus pemilu yang mempunyai kewenangan untuk memeriksa, mengadili dan memutus perkara hukum pemilu, sebagaimana peradilan khusus lainnya yang mempunyai kewenangan menangani perkara yang menjadi kewenangannya berdasarkan ruang lingkup perkara hukumnya.

Persoalan besar yang dihadapi sekarang ini adalah bagaimana menyiapkan perangkat hukum yang lebih responsif agar masa mendatang perkara pemilu dapat di selesaikan dangan memberikan keadilan pada para pihak yang merasa dirugikan dalam penyelenggaraan pemilu. Maka penulis mempunyai gagasan perlunya pembentukan peradilan khusus pemilu sebagai upaya penegakan hukum pemilu dalam pemberian kepastian hukum manakala ada pihak yang merasa dirugikan dalam penyelenggaraan pemilu.

Pembentukan peradilan khusus pemilu harus ditentukan terlebih dahulu kewenangannya, apakah menempel di Mahkamah Agung, atau dibuat badan peradilan khusus tersendiri, jika menempel di Mahkamah Agung, peradilan khusus pemilu bisa menempel di Pengadilan Negeri atau bisa juga bisa menempel di Pengadilan Tinggi, Selain itu harus ditentukan juga hukum acaranya, untuk menentukan hukum acaranya bisa melihat pedoman beracara Mahkamah Konstitusi yang selama ini terbukti efektif. ${ }^{11}$

Mengacu sebagaimana ketentuan di atas maka peradilan khusus pemilu yang akan dibentuk nantinya berwenang menangani perkara hukum pidana dan administrasi pemilu,

11 Wawancara dengan Arif Hidayat Hakim Mahkamah Konstitusi RI, Semarang, 28 April 2018 Pukul $12.03 \mathrm{WIB}$ 
berkedudukan di tingkat pusat dan provinsi, selanjutnya Adapun pedoman beracara pada peradilan khusus pemilu bisa menggunakan Peraturan Mahkamah Konstitusi Nomor 17 Tahun 2007 tentang Pedoman Beracara Dalam Perselisihan Hasil Pemilihan Umum Presiden Dan Wakil Presiden, atau bisa juga menggunakan Peraturan Mahkamah Konstitusi Nomor 16 Tahun 2009 tentang Pedoman Beracara Dalam Perselisihan Hasil Pemilihan Umum Anggota Dewan Perwakilan Rakyat, Dewan Perwakilan Daerah, Dan Dewan Perwakilan Rakyat Daerah. Bisa juga menggunakan Peraturan Mahkamah Agung Nomor 4 Tahun 2017 tentang Tata Cara Penyelesaian Pelanggaran Administratif Pemilihan Umum Mahkamah Agung.

Melihat pengalaman selama penyelenggaraan pemilu, peserta pemilu lebih takut terhadap sanksi administrasi dari pada sanksi pidana. Dalam data DKPP selama 6 Tahun terdapat seribu lebih perkara yang di tangani oleh DKPP dalam memeriksa terhadap dugaan pelanggaran kode etik penyelenggara. Lebih bagus dibentuk peradilan khusus pemilu. karena model penyelesaian sengketa dan penegakan hukum selama ini terlalu banyak yang mengurus, ada di Bawaslu, TUN, Pengadilan Negeri, DKPP dan MK, sehingga perlu dibentuk peradilan khusus supaya lebih memberikan kepastian hukum, sehingga pemilu selesai dan seluruh sengketa juga harus sudah diputus, supaya masyarakat percaya terhadap hasil pemilu, jangan sampai pemilu selesai masih ada sisa-sisa perkara yang belum selesai.

Hakim pengadilan khusus kedudukannya berada di tingkat pusat dan provinsi, hakim khusus di pusat ada 9 (Sembilan), 3 (tiga) direkrut oleh Mahkamah Agung, 3 (tiga) oleh DPR, dan 3 (tiga) oleh pemerintah, sedangkan di provinsi 7 (tujuh) orang hakim. Pengadilan khusus pemilu tidak merupakan pengadilan ad hoc, melainkan pengadilan khusus pemilu permanen. ${ }^{12}$ Pengadilan khusus pemilu merupakan badan yang independen dalam menjalankan fungsinya. ${ }^{13}$ Hakim-hakim pengadilan khusus pemilu yang memiliki kompetensi dalam bidang pemilu dan hukum administrasi pemilu, dapat disiapkan oleh Mahkamah Agung yang merupakan lembaga peradilan tertinggi. ${ }^{14}$

Sebagaimana pada uraian diatas supaya lebih efektif dalam penegakan hukum pemilu yang semula penegakannya dari berbagai lembaga, supaya lebih efektif dalam penegakan hukum pemilu maka perlu dibentuk peradilan khusus pemilu yang khusus berwenang menyelesaikan perkara hukum pemilu, peradilan khusus pemilu yang bersifat permanen berada di tingkat pusat dan provinsi, sedangkan untuk hakim yang berada di tingkat pusat berjumlah 9 (Sembilan) orang hakim, hanya saja untuk hakim terdiri dari 2 (dua) orang hakim direkrut dari pemerintah, 2 (dua) orang dari DPR, 2 (dua) orang dari Mahkamah Agung dan 3 (tiga) orang bisa dari KPU, Bawaslu, atau hakim karir yang menguasai hukum kepemiluan dan berpengalaman. Untuk di provinsi terdiri dari 7 (tujuh) orang hakim, 4 (empat) orang hakim dari Mahkamah Agung dan 3 (tiga) orang hakim bisa dari KPU, Bawaslu, atau hakim karir yang menguasai hukum kepemiluan dan berpengalaman. Persyaratan dan mekanisme perekrutan nantinya ditentukan oleh Mahkmah Agung.

12 Wawancara dengan Ida Bhudiati Dewan Kehormatan Penyelenggara Pemilu RI, Semarang, 25 Mei 2018, Pukul 13.41 WIB.

${ }^{13}$ Bisariyadi, B., Triningsih, A., Rahmawaty, H., \& Harumdani, W. (2012). Komparasi Mekanisme Penyelesaian Sengketa Pemilu Di Beberapa Negara Penganut Paham Demokrasi Konstitusional. Jurnal Konstitusi. 9(3). h. 531-562

${ }^{14}$ Saragih, A. D. A. (2017). Tinjauan Yuridis Pentingnya Pembentukan Peraadilan Khusus Dalam Pemilu Serentak Menurut Undang-Undang Pemilihan Kepala Daerah. Jurnal Lex et Societatis. 5(3). 
Sebagaimana pada ketentuan diatas syarat pada hakim khusus dalam peradilan khusus pemilu bisa mengacu pada Peraturan Mahkamah Agung Nomor 6 Tahun 2017 Tentang Hakim Khusus Dalam Sengketa Proses Pemilihan Umum Di Pengadilan Tata Usaha Negara, Pada ketentuan Pasal 3 ayat (1), (2), Pasal 4 dan Pasal 5, sebagai berikut: Pasal 3 ayat (1) menyebutkan bahwa “Ketua Pengadilan Tata Usaha Negara mengusulkan hakim pengadilan tata usaha negara yang sudah memenuhi kriteria atau syarat yang ditentukan oleh undang-undang kepada Ketua Mahkamah Agung untuk menjadi Hakim Khusus." ayat (2) menyebutkan bahwa "Ketua Pengadilan Tata Usaha Negara mengusulkan paling sedikit 3 (tiga) hakim dengan mempertimbangkan jumlah perkara pada masing-masing pengadilan tata usaha negara."

Pasal 4 menyebutkan bahwa "Ketua Mahkamah Agung menetapkan Hakim Khusus yang diusulkan Ketua Pengadilan Tata Usaha Negara." Pasal 5 menyebutkan bahwa "Persyaratan Hakim Khusus terdiri dari atas:

a. hakim karir yang menguasai pengetahuan tentang pemilihan umum; dan

b. telah melaksanakan tugasnya sebagai hakim minimal 3 (tiga) tahun, kecuali apabila dalam suatu pengadilan tidak terdapat hakim yang masa kerjanya telah mencapai 3 (tiga) tahun.

Agar penyelesaian pelanggaran pemilu bisa berjalan efektif dan berkualitas, maka ada tahapan yang harus diatur dan dilaksanakan secara komprehensif dan tuntas. Pertama, penyelesaian sengketa yang berkaitan dengan administrasi harus sudah diselesaikan secara tuntas oleh KPUD dan Bawaslu sebelum dimulainya masa kampanye. Kedua, penyelesaian tindak pidana pemilu harus diselesaikan secara cepat oleh aparat hukum terkait sebelum masa perhitungan suara berlangsung atau paling tidak sebelum ditetapkannya pemenang. Penyelesaian terkait perhitungan suara harus diselesaikan secara efektif dan cepat, sehingga tidak menimbulkan gangguan terhadap stabilitas pemerintahan. ${ }^{15}$

Sebagaimana uraian diatas maka penyelesaian pemilu agar bisa efektif dan berkualitas ada tahapan yang harus diatur dan dilaksanakan secara komprehensif dan tuntas, mengacu sebagaimana hal tersebut bisa mengacu pada ketentuan Pasal 467 ayat (4), Pasal 468 ayat (2), dan Pasal 469 ayat (1) Undang-Undang Nomor 7 Tahun 2017 tentang Pemilihan Umum, sebagai berikut:

Pasal 467 ayat (4) menyebutkan bahwa "Permohonan penyelesaian sengketa proses pemilu sebagaimana dimaksud pada ayat (2) disampaikan paling lama 3(tiga) hari kerja sejak tanggal penetapan keputusan KPU, keputusan KPU Provinsi, dan/atau keputusan KPU kabupaten/kota yang menjadi sebab sengketa." Pasal 468 ayat (2) menyebutkan bahwa "Bawaslu, Bawaslu Provinsi, Bawaslu Kabupaten/Kota memeriksa dan memutus sengketa proses pemilu paling lama 12 (dua belas) hari sejak diterimanya permohonan." Pasal 469 ayat (1) menyebutkan Bahwa "Putusan Bawaslu mengenai penyelesaian sengketa proses pemilu merupakan putusan yang bersifat dan mengikat, kecuali putusan terhadap sengketa prose pemilu yang berkaitan dengan:

a. verifikasi partai politik peserta pemilu;

b. penetapan daftar calon tetap anggota DPR, DPD, DPRD provinsi, dan DPRD Kabupaten/Kota; dan c. penetapan Pasangan Calon.

Sebagaimana dari uraian yang telah disampaikan diatas maka peradilan khusus pemilu yang akan dibentuk nantinya berwenang menangani perkara hukum pidana dan administrasi pemilu, berkedudukan di tingkat pusat dan provinsi, selanjutnya masuk pada Pengadilan

15 Wawancara dengan Sri Sumanta Anggota Bawaslu Provinsi Jawa Tengah, Semarang 24 Mei 2018, Pukul 09.10 WIB 
Negeri atau Pengadilan Tinggi. Adapun pedoman beracara pada peradilan khusus pemilu berdasarkan Peraturan Mahkamah Agung Nomor 4 Tahun 2017 tentang Tata Cara Penyelesaian Pelanggaran Administratif Pemilihan Umum Di Mahkamah Agung. Adapun hakim peradilan khusus pemilu yang berada di tingkat pusat berjumlah 9 (Sembilan) orang hakim, hanya saja untuk hakim terdiri dari 2 (dua) orang hakim direkrut dari pemerintah, 2 (dua) orang dari DPR, 2 (dua) orang dari Mahkamah Agung dan 3 (tiga) orang bisa dari KPU, Bawaslu, atau hakim karier yang menguasai hukum kepemiluan dan berpengalaman. Untuk di provinsi terdiri dari 7 (tujuh) orang hakim, 4 (empat) orang hakim dari Mahkamah Agung dan 3 (tiga) orang hakim bisa dari KPU, Bawaslu, atau hakim karir yang menguasai hukum kepemiluan dan berpengalaman. Persyaratan dan mekanisme perekrutan nantinya ditentukan oleh Mahkamah Agung.

Dalam hal tindak pidana pemilu yang tuntutannya di bawah 18 dilakukan di Pengadilan Negeri, hal tersebut sebagai pembatas mana yang ditangani di Pengadilan Negeri dan mana yang langsung di Pengadilan Tinggi. Pembentukan peradilan khusus untuk maksud memenuhi tuntutan perkembangan akan keadilan yang semakin kompleks dalam masyarakat. Ide-ide baru untuk membentuk pengadilan khusus pada umumnya dimaksudkan untuk lebih mengefektifkan upaya penegakan hukum di bidang-bidang tertentu. ${ }^{16}$ Sebagaimana dikutip dari Jurnal konstitusi, bahwa Sudikno Martukusomo menyebutkan "kepastian hukum merupakan jaminan bahwa hukum tersebut dapat dijalankan dengan baik." 17 Sebagai konsekuensinya, maka perlunya penyempurnaan peraturan perundang-undangan yang terkait dengan pemilu Pilpres, dan Pilkada, sebaiknya peraturan perundang-undangan tersebut terkodifikasikan menjadi satu undang-undang menganai pemilu dan mencakup pengaturan mengenai: 18

1. Pemilu Anggota DPR, DPD, dan DPRD

2. Pemilu Presiden dan Wakil Presiden

3. Pemilu Kepala Daerah dan Wakil Kepala Daerah

Mengacu pada ketentuan diatas maka perlunya penyempurnaan peraturan perundangundangan cukup mencakup pemilu Anggota DPR, DPD, Presiden dan Wakil Presiden dan DPRD dalam satu undang-undang mengenai pemilu dan pengaturannya menangani perkara pemilu yang menjadi kewenangan peradilan khusus pemilu. Penyempurnaan peraturan perundang-undangan sebagaimana diatas memegang peran penting dalam rangka membangun sistem hukum dalam penegakan hukum pemilu, merupakan politik hukum sebagai cara yang hendak dipakai untuk mencapai tujuan melalui sistem peradilan khusus dalam penegakan hukum pemilu.

Sebagaimana dikutip dari bukunya Abdul Aziz Hakim, bahwa Sadjipto Rahardjo mendefinisikan politik hukum sebagai aktivitas memilih dan cara yang hendak dipakai untuk mencapai suatu tujuan sosial dengan hukum tertentu di dalam masyarakat yang cakupannya meliputi jawaban atas beberapa pertanyaan, yaitu: ${ }^{19}$

1. Tujuan apa yang hendak dicapai melalui system yang ada.

${ }^{16}$ https:// www.scribd.com/doc/251903683/Pengadilan-Khusus-di-Indonesia(Diakses 3 Mei 2018)

17 Jurnal Konstitusi. (2016). Volume 13 Nomor 2. h. 285

18 Fadjar, M. A.(2013. Op.Cit. h. 110

${ }^{19}$ Hakim, A. A. (2011). Negara Hukum Dan Demokrasi Di Indonesia, Pustaka Pelajar. Yogyakarta. h. 3 
2. Cara-cara apa yang dan yang mana dirasa paling baik untuk dicapai dalam mencapai tujuan tersebut.

3. Kapan waktunya dan melalui cara bagaimana hukum itu perlu diubah.

4. Dapatkah suatu pola yang baku dan mapan dirumuskan untuk membantu dan memutuskan proses pemilihan tujuan serta cara-cara untuk mencapai tujuan tersebut dengan baik.

Adapun pedoman beracara pada peradilan khusus pemilu berdasarkan pada Peraturan Mahkamah Agung Nomor 4 Tahun 2017 tentang Tata Cara Penyelesaian Administratif Pemilihan Umum Di Mahkamah Agung. Sebagaimana pokok uraian diatas tentang pembentukan peradilan khusus pemilu, apabila peradilan khusus ini di perlakukan maka harus ada kodifikasi pengaturan pemilu sebagaimana diatas sebagai payung hukum dalam penyelesaian perkara pemilu, tentu saja peraturan terkait pemilu saat ini tidak diberlakukan, karena undang-undang pemilu yang menyangkut pembentukan peradilan khusus pemilu sebagaimana harus diposisikan sebagai lex specialis. Makna hukumnya bahwa keberlakuan undang-undang pemilu tentang pembentukan peradilan khusus pemilu adalah bersifat khusus.

Penjabaran argumentasi hukumnya secara normatif adalah dengan melihat ketentuan Pasal 63 ayat (2) KUHP mengatur bahwa "Jika suatu perbuatan masuk dalam suatu aturan pidana yang umum, diatur pula dalam aturan pidana yang khusus, maka yang khusus itulah yang diterapkan." Pasal 63 ayat (2) KUPH ini menegaskan keberlakuan (validitas) aturan pidana yang khusus ketika mendapati suatu perbuatan yang masuk, baik ke dalam aturan pidana yang umum dan aturan pidana yang khusus. Dalam ketentuan Pasal 63 ayat (2) KUHP terkandung adagium lex specialis derogate legi generalis yang merupakan suatu asas hukum yang mengandung makna dasar bahwa aturan yang bersifat khusus (specialis) mengesampingkan aturan yang bersifat umum (general). Berdasarkan asas lex specialis derogate legi generalis, aturan yang bersifat umum itu tidak lagi memiliki validity sebagai hukum ketika telah ada aturan yang bersifat khusus, aturan yang khusus tersebut sebagai hukum yang valid, yang mempunyai kekuatan mengikat untuk diterapkan terhadap peristiwa-peristiwa konkrit. ${ }^{20}$

Untuk dipahami secara teoritik, bahwa terdapat beberapa prinsip yang harus diperhatikan dalam adagium lex specialis derogate legi generalis, yaitu:

1. Ketentuan-ketentuan yang didapati dalam aturan hukum umum tetap berlaku, kecuali yang diatur khusus dalam aturan hukum khusus tersebut.

2. Ketentuan-ketentuan lex specialis harus sederajat dengan ketentuan lex generalis (undangundang dengan undang-undang).

3. Ketentuan-ketentuan lex specialis harus berada dalam lingkungan hukum (rezim) yang sama dengan lex generalis.

\section{Kesimpulan}

Urgensi pembentukan Peradilan Khusus Pemilu adalah untuk memenuhi tuntutan perkembangan akan keadilan yang semakin kompleks dalam masyarakat dan lebih penegakan hukum pemilu sehingga mewujudkan integritas pemilu, juga untuk menangani perkara hukum pemilu dengan cepat dan sederhana sehingga mewujudkan integritas pemilu. Formulasi pembentukan peradilan khusus pemilu dalam rangka mewujudkan integritas pemilu meliputi: Kedudukan Peradilan Khusus Pemilu, Formulasi Hakim Pada Peradilan Khusus, Pedoman

${ }^{20} \mathrm{http}: / /$ kpu-bimakab.go.id/detailpost/ kuhp-wvs-dalam-perspektif-peraturan-perundang-undanganpemilu-dan-atau-pemilihan-telaah-yuridis-teor. (Diakses 14 Mei 2018). 
beracara pada peradilan khusus pemilu berdasarkan pada Peraturan Mahkamah Agung Nomor 4 Tahun 2017 tentang Tata Cara Penyelesaian Pelanggaran Administratif Pemilihan Umum di Mahkamah Agung. Keberadaan Peradilan Khusus pemilu yang menangani perkara khusus memerlukan pengaturan pemilu sebagai perwujudan sistem ketatanegaraan yang demokratis dan berintegritas demi menjamin konsistensi dan kepastian hukum, sehingga terwujudnya integritas pemilu dan berkeadilan.

\section{Daftar Pustaka}

Buku

Abdulkadir Muhamad. (2014). Hukum dan Penelitian Hukum. Bandung: Citra Aditya Bakti.

Fadjar, A. M. (2013). Pemilu Perselisihan Hasil Pemilu dan Demokrasi (Membangun Pemilu Legislatif, Presiden, dan Kepala Daerah \& Penyelesaian Perselisihaan Hasil Pemilu Secara Demokratis). Malang: Setara Presss.

Hakim, A. A. (2011). Negara Hukum Dan Demokrasi di Indonesia. Yogyakarta: Pustaka Pelajar.

Sodikin. (2014). Hukum Pemilu; Pemilu Sebagai Praktek Ketatanegaraan. Bekasi: Gramata Publishing.

\section{Jurnal}

Arrsa, R. C. (2014). Pemilu Serentak dan Masa Depan Konsolidasi Demokrasi. Jurnal Konstitusi. 11(3). 515-537

Bisariyadi, B., Triningsih, A., Rahmawaty, H., \& Harumdani, W. (2012). Komparasi Mekanisme Penyelesaian Sengketa Pemilu Di Beberapa Negara Penganut Paham Demokrasi Konstitusional. Jurnal Konstitusi. 9(3). 531-562

Mujiatun, M. (2017). Permasalahan Hukum Terhadap Pelanggaran Pemilu. Jurnal An-Nur. 1(01). 58-69

Makhsid, W. (2015). Upaya Panitia Pengawas Pemilu Kabupaten Banyumas Dalam Pencegahan Tindak Pidana Money Politic Pada Pemilihan Umum Legislatif Tahun 2014. Jurnal Idea Hukum. 1(2). 171-182. http://dx.doi.org/10.20884/jih.v1i2.22

Saragih, A. D. A. (2017). Tinjauan Yuridis Pentingnya Pembentukan Peraadilan Khusus Dalam Pemilu Serentak Menurut Undang-Undang Pemilihan Kepala Daerah. Jurnal Lex et Societatis. 5(3). 167-175.

Saraswati, R. (2014). Reorientasi Hukum Pemilukada yang Mensejahterakan Rakyatnya. Jurnal Dinamika Hukum. 14(2). 359-367 http://dx.doi.org/10.20884/1.jdh.2014.14.2.303

Prasetyoningsih, N. (2014). Dampak Pemilihan Umum Serentak Bagi Pembangunan Demokrasi Indonesia. Jurnal Media Hukum. 21(2). 241-263 


\section{Website}

Arsil. (2008, Juli 22). Pengadilan-Pengadilan Khusus di Indonesia. https://tiarramon.wordpress.com/2010/07/14/pengadilan-pengadilan-khusus-diindonesia . accessed 3 Mei 2018.

Jimly Asshiddiqie. Pengadilan Khusus. https://www.scribd.com/doc/251903683/PengadilanKhusus-di-Indonesia . accessed 3 Mei 2018.

Yuddin Chandra Nan Arif. (2016, Mei 20). KUHP WvS Dalam Perspektif Peraturan PerundangUndangan Pemilu Dan/Atau Pemilihan Telaah Yuridis-Te. $\underline{\text { http://kpu- }}$ bimakab.go.id/detailpost/kuhp-wvs-dalam-perspektif-peraturan-perundangundangan-pemilu-dan-atau-pemilihan-telaah-yuridis-teor . accessed 14 Mei 2018. 